\title{
Acetaminophen-induced Acute Liver Injury in HCV Transgenic Mice
}

\author{
Takeki Uehara ${ }^{1}$, Oksana Kosyk ${ }^{1}$, Emmanuelle Jeannot ${ }^{1}$, Blair U. Bradford ${ }^{1}$, Katherine \\ Tech $^{2}$, Jeffrey M. Macdonald ${ }^{2}$, Gary A. Boorman ${ }^{3}$, Saurabh Chatterjee ${ }^{4}$, Ronald P. Mason ${ }^{4}$, \\ Stepan B. Melnyk ${ }^{5}$, Volodymyr P. Tryndyak ${ }^{6}$, Igor P. Pogribny ${ }^{6}$, and Ivan Rusyn ${ }^{1}$ \\ ${ }^{1}$ Department of Environmental Sciences \& Engineering, University of North Carolina, Chapel Hill, \\ NC 27599 \\ ${ }^{2}$ Department of Biomedical Engineering, University of North Carolina, Chapel Hill, NC 27599 \\ ${ }^{3}$ Covance, Chantilly, VA 20151 \\ ${ }^{4}$ Laboratory of Toxicology and Pharmacology, National Institute of Environmental Health \\ Sciences, RTP, NC 27713 \\ ${ }^{5}$ Department of Pediatrics, University of Arkansas for Medical Sciences, Little Rock, AR 72201 \\ ${ }^{6}$ Division of Biochemical Toxicology, National Center for Toxicological Research, Jefferson, AR \\ 72079
}

\begin{abstract}
The exact etiology of clinical cases of acute liver failure is difficult to ascertain and it is likely that various co-morbidity factors play a role. For example, epidemiological evidence suggests that coexistent hepatitis $\mathrm{C}$ virus (HCV) infection increased the risk of acetaminophen-induced acute liver injury, and was associated with an increased risk of progression to acute liver failure. However, little is known about possible mechanisms of enhanced acetaminophen hepatotoxicity in HCV-infected subjects. In this study, we tested a hypothesis that HCV-Tg mice may be more susceptible to acetaminophen hepatotoxicity, and also evaluated the mechanisms of acetaminophen-induced liver damage in wild type and HCV-Tg mice expressing core, E1 and E2 proteins. Male mice were treated with a single dose of acetaminophen ( 300 or $500 \mathrm{mg} / \mathrm{kg}$ in fed animals; or $200 \mathrm{mg} / \mathrm{kg}$ in fasted animals; i.g.) and liver and serum endpoints were evaluated at 4 and $24 \mathrm{hrs}$ after dosing. Our results suggest that in fed mice, liver toxicity in HCV-Tg mice is not markedly exaggerated as compared to the wild-type mice. In fasted mice, greater liver injury was observed in HCV-Tg mice. In fed mice dosed with $300 \mathrm{mg} / \mathrm{kg}$ acetaminophen, we observed that liver mitochondria in HCV-Tg mice exhibited signs of dysfunction showing the potential mechanism for increased susceptibility.
\end{abstract}

\footnotetext{
(C) 2012 Elsevier Inc. All rights reserved.

Correspondence: Ivan Rusyn, M.D., Ph.D., Department of Environmental Sciences and Engineering, University of North Carolina, Chapel Hill, NC 27599-7431, Phone/Fax (919) 843-2596, iir@unc.edu.

Conflict of Interest: The authors declare that there are no conflicts of interest.

Note: The views expressed in this manuscript do not necessarily represent those of the U.S. Food and Drug Administration.

Publisher's Disclaimer: This is a PDF file of an unedited manuscript that has been accepted for publication. As a service to our customers we are providing this early version of the manuscript. The manuscript will undergo copyediting, typesetting, and review of the resulting proof before it is published in its final citable form. Please note that during the production process errors may be discovered which could affect the content, and all legal disclaimers that apply to the journal pertain.
} 


\section{Keywords}

Hepatitis C virus; acetaminophen; liver; mouse; mitochondria; oxidative stress

\section{Introduction}

The prevalence of HCV infection is approximately $2.2-3.0 \%$ worldwide (130-170 million people), with the highest infection rates found in the African and the Eastern Mediterranean region (Lavanchy, 2009). After the asymptomatic phase, $\mathrm{HCV}$ infection develops into a chronic liver disease in most infected patients and results in liver damage, fibrosis, cirrhosis, liver failure and hepatocellular carcinoma (Tan et al., 2008). Despite major advances in diagnosis and treatment of HCV infection, it remains a growing public health issue in both developed and developing countries (Tsai and Chung, 2010). In the United States, the prevalence of $\mathrm{HCV}$ infection in the general population is similar to that worldwide; however, an increase in disease burden over the next decade is expected to occur (Kershenobich et al., 2011).

Acetaminophen (paracetamol, $N$-acetyl-para-aminophenol) is one of the most widely used pharmaceutical analgesic and antipyretic agents. While it is fairly inexpensive and effective for treatment of common aches and colds, an overdose of acetaminophen can cause acute liver injury (Larson et al., 2005). For example, more than a third of all cases involving acute liver failure in the United States alone are due to overdose of acetaminophen (Lee, 2003); and the majority of these cases are unintentional overdose or involve chronic intake (Kaplowitz, 2005). In addition, it has been estimated that $10 \%$ of patients experiencing liver failure due to acetaminophen were taking the drug at recommended doses (Lee, 2007). Even in healthy adult volunteers who received the maximum therapeutic dose for up to 14 days, about one-third exhibited transient, asymptomatic elevations in serum alanine aminotransferase (ALT) levels (Watkins et al., 2006; Harrill et al., 2009). At the same time, several clinical studies and comprehensive reviews of clinical data provide no evidence that acetaminophen, when used as directed, is associated with liver injury (Dart et al., 2010; Lavonas et al., 2010).

Liver injury due to acetaminophen is a complex phenotype, requiring accumulation of its reactive metabolite, $\mathrm{N}$-acetyl- $p$-benzoquinone imine (NAPQI), covalent binding to cellular proteins, oxidative stress, and hepatocellular necrosis, as well as an imbalance between protective and injurious cytokines (Jaeschke and Bajt, 2006). Many factors may facilitate acetaminophen-induced acute liver injury such as excessive alcohol consumption, concomitant use of narcotics, co-treatment with cytochrome P450 2E1 enzyme-inducing xenobiotics, or drugs affecting the glucuronidation pathway (Schmidt et al., 2002; Larson et al., 2005).

A re-analysis of the acetaminophen overdose cases from the Nationwide Inpatient Sample database (1998-2005) in the United States showed that coexistent HCV infection potentiated the hepatotoxicity of acetaminophen (Nguyen et al., 2008). Specifically, HCV significantly increased the risk of acute liver injury, and was also associated with an increased risk of progression to acute liver failure; however, there is no information concerning possible mechanisms of enhanced acetaminophen hepatotoxicity in $\mathrm{HCV}$-infected subjects. Human studies on acetaminophen overdose subjects who are HCV-positive may be difficult because coexistent $\mathrm{HCV}$ is present in only a small proportion of patients admitted for acetaminophen toxicity. Thus, HCV transgenic (HCV-Tg) mouse models, in which the HCV core and/or other proteins are expressed (Koike et al., 2010), may present a feasible alternative experimental model. 
In this study, we hypothesized that HCV-Tg mice may be more susceptible to acetaminophen hepatotoxicity and that the mechanisms for co-morbidity may be elucidated in an animal model. Male HCV-Tg mice expressing core, E1 and E2 proteins (Lerat et al., 2002) and wild-type C57BL/6J mice were gavaged with a single dose of acetaminophen ( 300 or $500 \mathrm{mg} / \mathrm{kg}$ under fed conditions, or $200 \mathrm{mg} / \mathrm{kg}$ under fasted conditions) and liver toxicity was evaluated at 4 and $24 \mathrm{hrs}$ after dosing. While this study shows that liver toxicity in HCV-Tg mice is not markedly exaggerated as compared to the wild-type mice, except when the animals are fasted, we observed that liver mitochondria in HCV-Tg mice exhibited signs of dysfunction in response to acetaminophen treatment.

\section{Materials and Methods}

\section{Animals and experimental design}

Male HCV-Tg mice (SL-139 strain, 15-30 weeks old) containing the structural genes (core, $\mathrm{E} 1$, E2, and p7, nucleotides 342-2771) of HCV genotype 1b, strain N, under the control of the murine albumin promoter/enhancer on C57BL/6J background (Korenaga et al., 2005) were used in the present study. Transgenic animals were identified after weaning by E2 gene polymerase chain reaction (PCR) on ear DNA as reported previously (Korenaga et al., 2005). Wild type C57BL/6J mice of the matching age were obtained from the Jackson Laboratory (Bar Harbor, ME). All animals were housed in polycarbonate cages on SaniChips irradiated hardwood bedding (P. J. Murphy Forest Products, Montville, NJ) and allowed free access to NTP-2000 diet (Zeigler Brothers, Gardners, PA) and water under a 12-h light-dark cycle. All studies were approved by the UNC Institutional Animal Care and Use Committee.

Mice were administered a single dose of acetaminophen $(300 \mathrm{mg} / \mathrm{kg}$; $99 \%$ pure; SigmaAldrich, St Louis, MO; $\mathrm{n}=8-10$ per group) or vehicle $(10 \mathrm{ml} / \mathrm{kg} ; 0.5 \%$ methyl 2hydroxyethyl cellulose; Sigma-Aldrich; $n=5-7$ per group) by oral gavage at approximately 9 a.m. without an overnight fast. Animals were sacrificed 4 or $24 \mathrm{hrs}$ after treatment via exsanguination by cutting both the abdominal aorta and vena cava under anesthesia (Nembutal ${ }^{\circledR} ; 100 \mathrm{mg} / \mathrm{kg}$, i.p.; Abbott Laboratories, Chicago, IL). Blood samples were collected from the vena cava. The liver was quickly removed following exsanguination, and sections of the left lateral and medial lobes were placed in $10 \%$ phosphate-buffered formalin for histopathology. Liver mitochondria were isolated from $100 \mathrm{mg}$ of fresh tissue, using a Mitochondria Isolation Kit for Tissue (Pierce, Rockford, IL) as previously described (Jeannot et al., 2012). Remaining liver tissue was snap frozen in liquid nitrogen and stored at $-80^{\circ} \mathrm{C}$ until used.

Separate groups of male mice (HCV-Tg or C57BL/6J, 20-25 weeks old) were treated with acetaminophen $(300 \mathrm{mg} / \mathrm{kg}$, no overnight fast) or vehicle as detailed above. In one experiment, [U_ ${ }^{13} \mathrm{C}$ ]glucose $(500 \mathrm{mg} / \mathrm{kg}, 2.78 \mathrm{mmol} / \mathrm{kg}$; Cambridge Isotopes, Andover, MA) was injected i.p. $3 \mathrm{hrs}$ and $15 \mathrm{~min}$ after treatment to evaluate glucose metabolism in the liver following acetaminophen treatment using nuclear magnetic resonance (NMR) spectroscopy as detailed by (Saito et al., 2010) with modifications as detailed below. Animals were sacrificed 4 hrs after dosing with acetaminophen or vehicle, and blood and liver samples were collected as detailed above.

In another experiment, mice were injected with the spin trap 5,5-dimethyl-1-pyrroline $\mathrm{N}$ oxide (DMPO, Alexis Biochemicals, San Diego, CA) i.p. in two doses of $1 \mathrm{~g} / \mathrm{kg}$ (diluted in sterile phosphate-buffered saline, $15 \mathrm{ml} / \mathrm{kg}$ ) at 2 and $1 \mathrm{hrs}$ before sacrifice at $24 \mathrm{hrs}$ after a single dose of acetaminophen $(300 \mathrm{mg} / \mathrm{kg}$, no overnight fast) or vehicle. Serum ALT and aspartate aminotransferase levels were determined using Vitro350 analyzer (Ortho-Clinical Diagnostic, Rochester, NY). 
A separate experiment was conducted to evaluate the role of fasting. Groups of male mice (HCV-Tg or C57BL/6J, 8-10 weeks old) were treated with acetaminophen $(200 \mathrm{mg} / \mathrm{kg}$ in mice fasted overnight before treatment, or $500 \mathrm{mg} / \mathrm{kg}$ in fed animals) or vehicle as detailed above. Animals were sacrificed $24 \mathrm{hrs}$ after dosing with acetaminophen or vehicle, and blood and liver samples were collected as detailed above.

\section{Mitochondria glutathione measurements}

Levels of total, reduced (GSH) and oxidized (GSSG) glutathione were assessed in mitochondria (4 hrs samples only) using high-performance liquid chromatography with coulometric electrochemical detection as described previously (James et al., 2009).

\section{Liver histopathology and immunohistochemistry protocol}

Liver tissues were stored in formalin solution for $72 \mathrm{hrs}$ and then transferred to $70 \%$ ethanol. Formalin-fixed liver tissue was then embedded in paraffin, and $5 \mu \mathrm{m}$ sections were mounted on glass slides. Sections were stained with hematoxylin and eosin, and examined under light microscopy. Extent of liver necrosis was quantified by a point counting technique (Bammler et al., 2005). For immunohistochemistry, formalin fixed, paraffin-embedded liver sections were deparaffinized, rehydrated, hydrolyzed in $4 \mathrm{~N} \mathrm{HCl}$ at $37^{\circ} \mathrm{C}$ for $20 \mathrm{~min}$, incubated in pepsin solution (Dako Cytomation, Carpinteria, CA) at $37^{\circ} \mathrm{C}$ for $20 \mathrm{~min}$, and Peroxidase Blocking Reagent (Dako) for $5 \mathrm{~min}$ at $37^{\circ} \mathrm{C}$. Dako EnVision System HRP kit (all antibodies were diluted by saline containing $1 \%$ bovine serum albumin) was used for the detection of 4-hydroxynonenal (rabbit anti-4-hydroxynonenal (HNE, Alpha Diagnostics, San Antonio, TX, 1:200, $30 \mathrm{~min}$ ) or F4/80 (rat anti-mouse F4/80 antibody, Serotec, Raleigh, NC, 1:100 dilution, $60 \mathrm{~min}$ ). The reaction products were visualized using diaminobenzidine, sections were counter-stained with hematoxylin, dehydrated and mounted. The number of F4/80positive cells per $200 \times$ centrilobular field was determined under light microscopy. Five centrilobular areas were counted per tissue sample.

\section{Quantitative reverse transcription polymerase chain reaction (qRT-PCR)}

RNA was extracted from the $30 \mathrm{mg}$ of tissue derived from the left lobe of liver samples using the Qiagen RNeasy kit (Qiagen, Valencia, CA) according to the manufacturer's instructions. RNA concentration was measured using ND-1000 spectrophotometer (NanoDrop Technologies, Wilmington, DE) and quality was verified using 2100 BioAnalyzer (Agilent Technologies, Santa Clara, CA). Ten micrograms of total RNA was reverse transcribed in a final volume of $100 \mu l$ using the High Capacity Archive kit and random hexamers (Applied Biosystems, Foster City, CA), diluted 4-fold in water and stored at $-80^{\circ} \mathrm{C}$. For each sample, $2 \mu \mathrm{l}$ of cDNA, corresponding to $25 \mathrm{ng}$ of reverse transcribed RNA, was analyzed in duplicate, using the LightCycler®480 Instrument (Roche Applied Science, Indianapolis, IN). Following primers were obtained from Applied Biosystems: heme oxygenase (decycling) 1 (Hmox1, Mm00516005_m1) and DNA-damage inducible transcript 3 (Ddit3/Chop, Mm00492097_m1). The relative amount of target gene mRNAs was determined using the $2^{-\Delta \Delta C T}$ method (Schmittgen and Livak, 2008) and expression was normalized to internal control TATA box binding protein (Tbp, Mm00446971_m1). Total serum RNA, including microRNA (miRNA), was isolated using QIAzol reagent (Qiagen) according to the manufacturer's instructions with minor modifications as detailed in (Tryndyak et al., 2012). The efficiency of small RNA isolation was monitored by using spiked miRNA and TaqMan miRNA assays (Applied Biosystems). Total RNA (1.5 $\mu l$ per reaction) was used for qRT-PCRs of miR-122, miR-34a, miR-200b, miR-192, miR-221, and miR-181a using TaqMan assays (Applied Biosystems), according to the manufacturer's instructions. The relative amount of each miRNA was measured using the $2^{-\Delta \Delta \mathrm{Ct}}$ method and normalized to mmu-miR-16, a ubiquitous non-liver-specific miRNA. 


\section{Immuno-spin trapping detection of oxidative stress-induced protein and DNA adducts}

A technique of immuno-spin trapping was used to evaluate hepatic oxidative stress levels (Chatterjee et al., 2011) following treatment with acetaminophen. Livers of the mice treated with DMPO before sacrifice (see procedure above) were fixed in $10 \%$ neutral buffered formalin, soaked in $30 \%$ sucrose for $24 \mathrm{hrs,} \mathrm{embedded} \mathrm{into} \mathrm{OCT} \mathrm{(optimal} \mathrm{cutting}$ temperature) compound and stored at $-80^{\circ} \mathrm{C}$. Frozen sections $(10 \mu \mathrm{m})$ were cut using a frozen tissue processor (Leica Instruments, Bannockburn, IL, USA). Immunohistochemistry was performed as detailed in (Chatterjee et al., 2011) using antibody specific to DMPO nitrone adducts and Alexafluor 568 goat anti-rabbit secondary antibody (Molecular Probes/ Invitrogen, Eugene, OR). Confocal images were taken on a Zeiss LSM510-UV Meta microscope (Carl Zeiss, Oberkochen, Germany). The 488-nm line from an argon laser was used for producing polarized light for a DIC image as well as fluorescence excitation of the Alexa 488 secondary antibody. Metamorph imaging software (v.7.7. Molecular Devices LLC, Sunnyvale, CA) was used to calculate the fluorescence intensity of the groups. Specifically, Metamorph was used to open each image and then apply an inclusive threshold between 30-255 gray levels. The total integrated intensity of each thresholded image was then calculated and exported for analysis.

\section{Liver Extraction and NMR sample Preparation}

The Folch method was used to extract the water-soluble metabolites (Folch et al., 1957). Aqueous portion of the liver extract were frozen and placed in the speedvac to lyophilize overnite. To each tube was added $30 \mu \mathrm{l}$ of $\mathrm{D}_{2} \mathrm{O}$ containing $0.1 \% \mathrm{NaN}_{3}$ and $1 \mathrm{mM}$ trimethylsilyl propionic acid. Each tube was sonicated, then vortexed to effect dissolution. The tubes were place in a Fisher Scientific accuSpin Micro 17R centrifuge and spun at 5kG for 20 minutes to collect all the liquid at the bottom of each vial. A Neptune barrier pipette tip was cut off below the filter media and placed in the top of a $9 \mathrm{~mm}$ Microliter Analytical sample vial. Each sample was transferred to the top of a barrier pipette tip for filtration by centrifugation to force the sample through the filter media. The samples were spun for 10 minutes at $2200 \mathrm{rpm}$ on a Beckman GS-6R centrifuge. The filter tips were removed and a cap was placed on each vial.

\section{${ }^{1} \mathrm{H}$ and ${ }^{13} \mathrm{C}$ Nuclear Magnetic Resonance (NMR) Spectroscopy}

All ${ }^{1} \mathrm{H}$ NMR spectroscopy was performed on a Varian INOVA spectrometer (Agilent, formerly Varian Inc., Palo Alto, CA) operating at $599.64 \mathrm{MHz}\left({ }^{1} \mathrm{H}\right.$ frequency) and $25^{\circ} \mathrm{C}$. The micro-coil probe is a Protasis/MRM 1011 capillary NMR probe (Magnetic Resonance Micro- sensors, Savoy, IN). Samples were introduced into the micro-coil using a Protasis High-throughput Sample Automation System (Protasis, Marlboro, MA). The pw90 was measured to be $11.1 \mu \mathrm{sec}$ at tpwr=45. An inversion recovery experiment was acquired to measure the T1 values, which was approximately $2.1 \mathrm{sec}$. This information was used to calculate the Ernst angle. A $70^{\circ}$ flip angle was used of $8 \mu$ s with 2048 transients, using a one pulse sequence with a $2 \mathrm{sec}$ presaturation pulse and $3 \mathrm{sec}$ repetition time. For ${ }^{13} \mathrm{C}$ NMR spectroscopy, the same samples run for ${ }^{1} \mathrm{H}$ NMR spectroscopy were dried and resuspended in $25 \mu \mathrm{l}$ of $\mathrm{D}_{2} \mathrm{O}$. All ${ }^{13} \mathrm{C}$ NMR spectroscopy was performed on a Varian INOVA spectrometer (Agilent) operating at $150 \mathrm{MHz}\left({ }^{13} \mathrm{C}\right.$ frequency) and $25^{\circ} \mathrm{C}$. A Varian broadband cryoprobe was used (Magnetic Resonance Micro-sensors, Savoy, IN). A $30^{\circ}$ flip angle was used of $2 \mu \mathrm{s}$ with 13000 transients, using a one pulse sequence with a $3 \mathrm{sec}$ repetition time with WALTZ ${ }^{1} \mathrm{H}$ decoupling during acquisition.

\section{Statistical analysis}

Statistical significance was determined by one-way analysis of variance (ANOVA) followed by Bonferroni post-hoc test. Results were considered significant at $p<0.05$. 


\section{Results}

Liver toxicity was assessed in fed wild type C57BL/6J and HCV-Tg mice at $24 \mathrm{hrs}$ after i.g. administration of a single large dose $(300 \mathrm{mg} / \mathrm{kg})$ of acetaminophen. In both mouse groups, liver injury was observed and was histopathologically characterized as centrilobular necrosis with inflammatory cell infiltration (Figure 1A). Serum markers of liver injury, activity of ALT (Figure 1B) and AST (data not shown), were markedly elevated in both WT and HCV$\mathrm{Tg}$ groups receiving acetaminophen. No significant effect was observed on the serum levels of ALP and albumin (data not shown). The extent of liver necrosis, assessed both as a qualitative pathology score, and as a quantitative measure of percent necrotic liver (Figure 1C) was also similar in both wild type and HCV-Tg mice. While Figure 1 presents data from all animals in each group, it should be noted that the characteristic histological changes were observed in 5/10 mice in the wild type group and in 5/8 mice in HCV-Tg group, an observation similar to the known animal-to-animal variability in the extent of acetaminophen-induced liver necrosis in the C57BL/6J mice (Beyer et al., 2007). The incidence of liver necrotic lesions was significantly increased in both APAP-treated groups compared to corresponding control groups $(p<0.05)$.

Several recent reports have demonstrated that circulating miRNAs may be a sensitive and independent indicator of liver injury (Cermelli et al., 2011; Tryndyak et al., 2012). Hence, we evaluated the level of miRNAs in serum of control and acetaminophen-treated mice. Serum levels of miR122 and miR192 (Figure 1D), as well as miR34a, miR200b, miR221, and miR181a (data not shown) were markedly increased in both acetaminophen-treated groups compared to corresponding control groups. Interestingly, the increase in serum levels of liver-specific miRNAs miR122 and miR192 (Gatti et al., 2011) was significantly greater in acetaminophen-treated HCV-Tg mice than in acetaminophen-treated wild type animals.

It has been suggested that ageing HCV-Tg mice may be prone to developing oxidative stress (Korenaga et al., 2005), we used animals that were 15 and 30 weeks of age in these experiments. No overt liver histopathological changes were found in vehicle-treated HCV$\mathrm{Tg}$ mice of either age group, similar to observations with other HCV-Tg models (Koike et al., 2010). There was no difference in acetaminophen-induced liver injury between different age groups in either wild type or HCV-Tg mice, therefore data on mice of all ages tested are combined in Figures 1 and 2.

Activation of the hepatic macrophages and recruitment of inflammatory cells from systemic circulation are known hallmarks of acetaminophen-induced liver injury (Adams et al., 2010). Since it has been suggested that HCV-Tg mice may be susceptible to disease-causing factors through liver inflammation (Korenaga et al., 2005; Nishina et al., 2008), we evaluated the number of mature Kupffer cells in the liver of treated mice (Figure 2A-B). Immunohistochemistry for F4/80, a specific marker of quiescent Kupffer cells, showed a significant decrease in the number of positively labeled cells in the livers of mice treated with acetaminophen. This observation is similar to that reported by (Dambach et al., 2002). While statistical significance was observed in the comparison between acetaminophentreated and corresponding control groups, there was no significant difference in the comparison between HCV-Tg and wild type mice.

Oxidative stress has been also suggested as a mechanism for increased susceptibility of HCV-Tg mice (Korenaga et al., 2005; Nishina et al., 2008) and acetaminophen is wellknown to cause liver injury via reactive oxygen species (Powell et al., 2006). To assess the degree of oxidative stress, several approaches were used. Lipid peroxidation was evaluated using 4-HNE-protein adducts as a marker (Figure 2C). Hepatocytes around the central vein exhibited weakly positive staining of 4-HNE in both vehicle-treated groups. Acetaminophen 
treatment resulted in an intense staining of hepatocytes, primarily in the centrilobular region with some animals exhibiting positive staining even in mid-lobular and periportal regions. There was no difference in 4-HNE staining intensity or zonality between HCV-Tg and wild type groups. In addition, we determined the mRNA level of heme oxygenase-1 (Hmox 1), one of several coordinately regulated proteins involved in protecting against liver injury which is inducible by a variety of hepatotoxicants (Choi et al., 2003). While acetaminophen induced Hmox 1 (Figure 2D), the magnitude of the effect was similar between wild type and HCV-Tg mice. Next, we used a method of immuno-spin trapping for detecting and localizing protein free radicals in tissues (Chatterjee et al., 2011). The sites of generation of free radical species in liver tissues post acetaminophen administration were localized with anti-DMPO antibody and confocal microscopy (Figure 3A). Results indicated that the accumulation of the radical adducts was most pronounced in the cells bordering the central vein (Figure 3B) and that the amount of the radical adducts formed was significantly elevated in HCV-Tg mice treated with acetaminophen as compared to vehicle-treated HCVTg mice (Figure 3C).

Unfolded protein response (endoplasmic reticulum [ER] stress) has been shown to be induced in the liver by a number of toxicants, including acetaminophen (Nagy et al., 2007). In turn, HCV has also been shown to cause ER stress both in vitro (Chan and Egan, 2005) and in vivo (Nishina et al., 2010), yet the latter findings have not been observed in all studies with HCV-Tg mice (Lerat et al., 2009). Thus, we investigated whether HCV-Tg mice exhibit signs of liver ER stress, and whether it may be potentiated by acetaminophen. While acetaminophen caused an increase (Figure 2E) in mRNA for CCAAT/enhancerbinding protein-homologous protein (Chop), as expected (Nagy et al., 2007), there was no difference in expression level of Chop or spliced X-box DNA binding protein-1 ( $x$ Xbpl, data not shown) between wild type and HCV-Tg mice treated with vehicle or acetaminophen.

In separate experiments, we evaluated the effect of dose and fasting on potential differences in acetaminophen-induced liver injury among wild type and HCV-Tg mice (Figure 4). In animals that were fasted overnight and then treated for $24 \mathrm{hrs}$ with $200 \mathrm{mg} / \mathrm{kg}$ of acetaminophen by gavage, we observed significant elevations in the degree of liver necrosis in both groups, and this effect in HCV-Tg animals was significantly greater than that in wild type mice (Figure 4A). In fed animals treated with $500 \mathrm{mg} / \mathrm{kg}$ of acetaminophen for $24 \mathrm{hrs}$ (Figure 4B), significant liver necrosis was observed in both wild type and HCV-Tg mice, albeit the differences between wild type and HCV-Tg animals were not significant.

While the histopathological evidence of acetaminophen-induced centrilobular liver injury is most pronounced $24 \mathrm{hrs}$ after administration of $300 \mathrm{mg} / \mathrm{kg}$ dose, the effects on liver and mitochondrial glutathione pool occur within hours of dosing (Mitchell et al., 1973). Thus, we also compared acetaminophen's liver effects at $4 \mathrm{hrs}$ after dosing with $300 \mathrm{mg} / \mathrm{kg}$ (in fed animals). As expected, no histopathological signs of overt liver injury were observed in both wild type and HCV-Tg mice (Figure 5A). Serum enzyme markers levels were higher in acetaminophen-treated groups, albeit the changes were not significant (Figure 5B). In liver mitochondria from vehicle-treated HCV-Tg mice, the amount of total glutathione was significantly higher than that in the wild type mice (Figure 5C). Treatment with acetaminophen led to a significant decrease in total mitochondrial GSH in HCV-Tg, but not wild type mice (Figure 5C).

Mitochondria are known to be the target for HCV proteins (Wang and Weinman, 2006) and recent in vitro evidence shows that HCV has a profound effect on cellular metabolism and energy homeostasis (Diamond et al., 2010). Thus, we investigated what is the outcome of HCV-Tg and acetaminophen treatment ( $300 \mathrm{mg} / \mathrm{kg}$ in fed mice) on the mitochondrial energy 
metabolism using [U-13 $\mathrm{C}$ ]glucose and nuclear magnetic resonance detection of Krebs cycle intermediates (Saito et al., 2010). The relative flux of carbon from $\left[\mathrm{U}-{ }^{13} \mathrm{C}\right]$ glucose through pyruvate dehydrogenase ( $\mathrm{PDH})$ and pyruvate carboxylase (PC) pathways was evaluated (Figure 6A). Specifically, we performed isotopomer analysis of glutamine moieties (Figure 6B) as detailed in (Carvalho et al., 1999). Our results show that in livers of vehicle-treated $\mathrm{HCV}-\mathrm{Tg}$ mice, as compared to wild type mice, there is a significant elevation in relative flux through PDH as compared to PC (Figure 6C). As shown previously (Saito et al., 2010), acetaminophen treatment does not result in a diminished flux through PDH 4 hrs after treatment with acetaminophen as no change in the relative flux through PC and PDH was observed in either HCV-Tg or wild type mice.

\section{Discussion}

$\mathrm{HCV}$ infection leads to progressive liver disease and a variety of underlying mechanisms including oxidative stress, steatosis, impaired immune and apoptotic responses, and iron accumulation have been implicated in the development of steatohepatitis, cirrhosis and hepatocellular carcinomas (Tsai and Chung, 2010). While the majority of HCV-infected individuals do not exhibit signs of liver disease (e.g., elevations of serum enzymes or signs of liver inflammation or fibrosis) (Alberti et al., 2002), it is becoming increasingly clear that even in the absence of clinical signs of liver injury, HCV-infected subjects may be more susceptible to other environmental or biological factors associated with liver disease (Nguyen et al., 2008; Puoti et al., 2010). Acute infection with viruses that target the liver also has been shown to increase the risk of liver injury from acetaminophen (Yaghi et al., 2006; Maddox et al., 2010). Thus, the goal of this study was to use an animal transgenic model of HCV to examine potential susceptibility to acetaminophen-induced liver injury, even though HCV-Tg mice do not exhibit signs of liver inflammation.

Few experimental models may faithfully replicate the pathophysiological state of the liver in $\mathrm{HCV}$ carriers who do not exhibit symptoms of liver disease, yet are in need of careful surveillance. On one hand, important discoveries have been made in our understanding of the role that inflammation plays in acute liver injury through co-exposures to a drug of interest and lipopolysaccharide or other inflammogens (Ganey et al., 2004; Jaeschke, 2008; Han et al., 2010). Inflammation is one of the most common pathways suggested as being responsible for interactions that could enhance liver injury (Roth and Ganey, 2010). Chronic inflammation may lead to sensitization to secondary xenobiotic-induced stress because many molecular events involved in the progression of liver injury are shared (Gunawan and Kaplowitz, 2007). However, it is not clear whether an animal model where acute liver injury is introduced as a co-factor is relevant to address the mechanisms of potential susceptibility in patients with chronic HCV infection who show persistently normal ALT levels. On the other hand, transgenic mice expressing various HCV proteins do not show signs of liver injury, inflammation or ER stress, at least in the first 12 months of age (Koike et al., 2010). The HCV-Tg mice are, however, known to be susceptible to exposures promoting liver disease and carcinogenesis (Furutani et al., 2006; Machida et al., 2009; Jeannot et al., 2012). Thus, we posit that while the HCV-Tg mouse model that was used in this study is not one to investigate the inflammation-related potentiation of liver injury, it may be highly relevant for recapitulating the state of the liver in human "asymptomatic" carriers of $\mathrm{HCV}$.

Several experimental designs were used in our study to evaluate putative susceptibility of HCV-Tg mice to acetaminophen. In fed mice, we did not observe a significant difference in the severity of liver histology or serum markers of liver injury between wild type and HCV$\mathrm{Tg}$ mice that were dosed with either 300 or $500 \mathrm{mg} / \mathrm{kg}$ of acetaminophen. Importantly, under overnight fasting conditions, a significant difference in liver injury among wildtype and 
HCV-Tg mice was observed when $200 \mathrm{mg} / \mathrm{kg}$ of acetaminophen was administered for 24 hrs.

The mitochondria are an early target for and a sensitive bellwether of acetaminopheninduced liver injury (Heinloth et al., 2004). Acetaminophen-induced mitochondrial dysfunction has been reported in vivo in mice (Jaeschke and Bajt, 2006), in vitro in human metabolically-active HepaRG cells (McGill et al., 2011), and in human subjects (McGill et al., 2012). In addition, mitochondria are a well-known target for HCV proteins (Sheikh et al., 2008). Mitochondrial energy metabolism is affected (Korenaga et al., 2005) and permeability transition induced (Machida et al., 2006) by HCV. Fasting has a profound impact on liver metabolism (Kopelovich and Sabine, 1970) and glutathione levels (Maruyama et al., 1968). Thus, even though greater liver injury was observed in fasted $\mathrm{HCV}-\mathrm{Tg}$ mice, we reasoned that mechanistic studies of the role of glutathione should be conducted under physiological fed conditions because of the potential central role of mitochondrial glutathione in the mechanism of susceptibility of HCV-Tg mice to acetaminophen-induced liver injury.

Increased oxidative stress was confirmed by intense positive staining of 4-HNE in the livers of both wild type and HCV-Tg mice treated with acetaminophen. Decreased number of F4/80 positive Kupffer cells is explained by the evidence that activation of Kupffer cells due to inflammation changes the pattern of expression of its membrane protein (Dambach et al., 2002). Furthermore, induction of Hmox 1, protein involved in the mechanisms of NF-E2related factor 2 (Nrf2)-related oxidative stress and Chop, a marker for ER stress, was observed in acetaminophen-treated groups. Interestingly, the results from immuno-spin trapping technique showed an increase in peri-central reactive oxygen species production in HCV-Tg mice treated with acetaminophen, but not in wild type animals. The apparent inconsistency between the results from different assays used here is not unexpected. First, we confirm a widely-known observation that oxidative stress is induced in the liver upon treatment with acetaminophen. Second, the immuno-spin trapping technique was used to successfully confirm the precise site in the liver lobule where reactive oxygen species have been postulated to be produced. This technique is assessing oxidant production in a very narrow window of time ( 2 hrs before sacrifice), while 4-HNE and gene expression assays are reflective of the effects occurring over the entire $24 \mathrm{hr}$ treatment period. Still, a detailed time-course investigation may be necessary to fully characterize the impact and kinetics of $\mathrm{HCV}-\mathrm{Tg}$ effect on formation of liver reactive oxygen species, a key mechanism of acetaminophen-induced liver injury.

We observed that HCV-Tg mice had higher basal total mitochondrial glutathione content than wild type mice, consistent with the observation that HCV-Tg mice may be prone to mitochondrial oxidative stress (Korenaga et al., 2005). Importantly, mitochondrial glutathione was affected by acetaminophen treatment in $\mathrm{HCV}-\mathrm{Tg}$, but not in wild type, mice 4 hrs after dosing. While these results are supportive of the HCV-induced sensitization of the mitochondria to exogenous stressors, we also determined whether mitochondrial energy metabolism may be affected in HCV-Tg mice. Similar to the observations of (Saito et al., 2010), acetaminophen did not result in a diminished flux through pyruvate dehydrogenase in wild type mice. Interestingly, the ratio of flux through pyruvate carboxylase versus pyruvate dehydrogenase was reduced significantly in HCV-Tg mice, as compared to wild type mice, which is indicative of an increase in pyruvate entry into the Krebs cycle via pyruvate dehydrogenase. In turn, this shows that more glucose-derived pyruvate is used for ATP generation rather than amino acid synthesis in HCV-Tg mice, even though the total mitochondrial glutathione pool is greater than that in wild type mice. The increased demand for ATP in HCV-Tg mice is consistent with the negative impact that HCV core protein has on the mitochondrial electron transport (Korenaga et al., 2005). 
In summary, this study used HCV-Tg mouse model to investigate the molecular mechanisms that may underlie the clinical observation of an increased risk of acute liver injury following acetaminophen overdose among subjects with coexistent HCV. This study is clinically relevant given the rising prevalence of $\mathrm{HCV}$ in the general population and that we used the animal model that is aimed to be reflective of the majority of HCV-infected subjects (Alberti et al., 2002) who do not exhibit signs of liver disease but may be susceptible to coexposures. While we observed that the degree of acetaminophen-induced liver injury in $\mathrm{HCV}-\mathrm{Tg}$ mice is not markedly exaggerated as compared to the wild-type mice, except under conditions of fasting, we show that liver mitochondria in HCV-Tg mice exhibited signs of functional strain both prior to, and following a toxic insult. In addition, albeit not addressed by the current study design, a possibility exists that the reported sensitization to acetaminophen in $\mathrm{HCV}$-infected patients may be due to events associated with viral replication, chronic inflammation, or viral proteins other than those tested using the HCV$\mathrm{Tg}$ model that was used. While encouraging, these findings, together with the clinical observation (Nguyen et al., 2008), require further confirmation from prospective clinical and mechanistic studies before they may be considered in clinical decision-making.

\section{Supplementary Material}

Refer to Web version on PubMed Central for supplementary material.

\section{Acknowledgments}

Supported, in part, by grants from the National Institutes of Health P42 ES005948 and R01 ES015241. Saurabh Chatterjee was a recipient of NIH K99/R00 award ES019875. The authors wish to acknowledge technical assistance from Drs. John Grimes, Marc ter Horst, and Thomas O'Connell. We are also grateful to Dr. Steven Weinman for providing the HCV-Tg animals and for fruitful discussions.

\section{Abbreviations}

$\begin{array}{ll}\text { HCV } & \text { Hepatitis C virus } \\ \text { NAPQI } & \text { N-acetyl- } p \text {-benzoquinone imine } \\ \text { ALT } & \text { alanine aminotransferase } \\ \text { GSH } & \text { glutathione } \\ \text { NMR } & \text { nuclear magnetic resonance }\end{array}$

\section{References}

Adams DH, Ju C, Ramaiah SK, Uetrecht J, Jaeschke H. Mechanisms of immune-mediated liver injury. Toxicol Sci. 2010; 115:307-321. [PubMed: 20071422]

Alberti A, Noventa F, Benvegnu L, Boccato S, Gatta A. Prevalence of liver disease in a population of asymptomatic persons with hepatitis C virus infection. Annals of internal medicine. 2002; 137:961964. [PubMed: 12484711]

Bammler T, Beyer RP, Bhattacharya S, Boorman GA, Boyles A, Bradford BU, Bumgarner RE, Bushel PR, Chaturvedi K, Choi D, Cunningham ML, Deng S, Dressman HK, Fannin RD, Farin FM, Freedman JH, Fry RC, Harper A, Humble MC, Hurban P, Kavanagh TJ, Kaufmann WK, Kerr KF, Jing L, Lapidus JA, Lasarev MR, Li J, Li YJ, Lobenhofer EK, Lu X, Malek RL, Milton S, Nagalla SR, O’Malley JP, Palmer VS, Pattee P, Paules RS, Perou CM, Phillips K, Qin LX, Qiu Y, Quigley SD, Rodland M, Rusyn I, Samson LD, Schwartz DA, Shi Y, Shin JL, Sieber SO, Slifer S, Speer MC, Spencer PS, Sproles DI, Swenberg JA, Suk WA, Sullivan RC, Tian R, Tennant RW, Todd SA, Tucker CJ, Van Houten B, Weis BK, Xuan S, Zarbl H. Standardizing global gene expression analysis between laboratories and across platforms. Nat Methods. 2005; 2:351-356. [PubMed: 15846362] 
Beyer RP, Fry RC, Lasarev MR, McConnachie LA, Meira LB, Palmer VS, Powell CL, Ross PK, Bammler TK, Bradford BU, Cranson AB, Cunningham ML, Fannin RD, Higgins GM, Hurban P, Kayton RJ, Kerr KF, Kosyk O, Lobenhofer EK, Sieber SO, Vliet PA, Weis BK, Wolfinger R, Woods CG, Freedman JH, Linney E, Kaufmann WK, Kavanagh TJ, Paules RS, Rusyn I, Samson LD, Spencer PS, Suk W, Tennant RJ, Zarbl H. Multicenter study of acetaminophen hepatotoxicity reveals the importance of biological endpoints in genomic analyses. Toxicol Sci. 2007; 99:326-337. [PubMed: 17562736]

Carvalho RA, Babcock EE, Jeffrey FM, Sherry AD, Malloy CR. Multiple bond 13C-13C spin-spin coupling provides complementary information in a 13C NMR isotopomer analysis of glutamate. Magnetic resonance in medicine : official journal of the Society of Magnetic Resonance in Medicine / Society of Magnetic Resonance in Medicine. 1999; 42:197-200. [PubMed: 10398967]

Cermelli S, Ruggieri A, Marrero JA, Ioannou GN, Beretta L. Circulating microRNAs in patients with chronic hepatitis $\mathrm{C}$ and non-alcoholic fatty liver disease. PloS one. 2011; 6:e23937. [PubMed: 21886843]

Chan SW, Egan PA. Hepatitis C virus envelope proteins regulate CHOP via induction of the unfolded protein response. FASEB J. 2005; 19:1510-1512. [PubMed: 16006626]

Chatterjee S, Lardinois O, Bhattacharjee S, Tucker J, Corbett J, Deterding L, Ehrenshaft M, Bonini MG, Mason RP. Oxidative stress induces protein and DNA radical formation in follicular dendritic cells of the germinal center and modulates its cell death patterns in late sepsis. Free radical biology \& medicine. 2011; 50:988-999. [PubMed: 21215311]

Choi BM, Pae HO, Kim YM, Chung HT. Nitric oxide-mediated cytoprotection of hepatocytes from glucose deprivation-induced cytotoxicity: involvement of heme oxygenase-1. Hepatology. 2003; 37:810-823. [PubMed: 12668974]

Dambach DM, Watson LM, Gray KR, Durham SK, Laskin DL. Role of CCR2 in macrophage migration into the liver during acetaminophen-induced hepatotoxicity in the mouse. Hepatology. 2002; 35:1093-1103. [PubMed: 11981759]

Dart RC, Green JL, Kuffner EK, Heard K, Sproule B, Brands B. The effects of paracetamol (acetaminophen) on hepatic tests in patients who chronically abuse alcohol - a randomized study. Alimentary pharmacology \& therapeutics. 2010; 32:478-486. [PubMed: 20491750]

Diamond DL, Syder AJ, Jacobs JM, Sorensen CM, Walters KA, Proll SC, McDermott JE, Gritsenko MA, Zhang Q, Zhao R, Metz TO, Camp DG 2nd, Waters KM, Smith RD, Rice CM, Katze MG. Temporal proteome and lipidome profiles reveal hepatitis $\mathrm{C}$ virus-associated reprogramming of hepatocellular metabolism and bioenergetics. PLoS pathogens. 2010; 6:e1000719. [PubMed: 20062526]

Folch J, Lees M, Sloane Stanley GH. A simple method for the isolation and purification of total lipides from animal tissues. J Biol Chem. 1957; 226:497-509. [PubMed: 13428781]

Furutani T, Hino K, Okuda M, Gondo T, Nishina S, Kitase A, Korenaga M, Xiao SY, Weinman SA, Lemon SM, Sakaida I, Okita K. Hepatic iron overload induces hepatocellular carcinoma in transgenic mice expressing the hepatitis C virus polyprotein. Gastroenterology. 2006; 130:20872098. [PubMed: 16762631]

Ganey PE, Luyendyk JP, Maddox JF, Roth RA. Adverse hepatic drug reactions: inflammatory episodes as consequence and contributor. Chem Biol Interact. 2004; 150:35-51. [PubMed: 15522260]

Gatti DM, Lu L, Williams RW, Sun W, Wright FA, Threadgill DW, Rusyn I. MicroRNA expression in the livers of inbred mice. Mutation research. 2011; 714:126-133. [PubMed: 21616085]

Gunawan BK, Kaplowitz N. Mechanisms of drug-induced liver disease. Clinics in liver disease. 2007; 11:459-475. v. [PubMed: 17723915]

Han D, Shinohara M, Ybanez MD, Saberi B, Kaplowitz N. Signal transduction pathways involved in drug-induced liver injury. Handbook of experimental pharmacology. 2010:267-310. [PubMed: 20020266]

Harrill AH, Ross PK, Gatti DM, Threadgill DW, Rusyn I. Population-based discovery of toxicogenomics biomarkers for hepatotoxicity using a laboratory strain diversity panel. Toxicol Sci. 2009; 110:235-243. [PubMed: 19420014] 
Heinloth AN, Irwin RD, Boorman GA, Nettesheim P, Fannin RD, Sieber SO, Snell ML, Tucker CJ, Li L, Travlos GS, Vansant G, Blackshear PE, Tennant RW, Cunningham ML, Paules RS. Gene expression profiling of rat livers reveals indicators of potential adverse effects. Toxicol Sci. 2004; 80:193-202. [PubMed: 15084756]

Jaeschke H. Innate immunity and acetaminophen-induced liver injury: why so many controversies? Hepatology. 2008; 48:699-701. [PubMed: 18752320]

Jaeschke H, Bajt ML. Intracellular signaling mechanisms of acetaminophen-induced liver cell death. Toxicol Sci. 2006; 89:31-41. [PubMed: 16177235]

James SJ, Rose S, Melnyk S, Jernigan S, Blossom S, Pavliv O, Gaylor DW. Cellular and mitochondrial glutathione redox imbalance in lymphoblastoid cells derived from children with autism. FASEB J. 2009; 23:2374-2383. [PubMed: 19307255]

Jeannot E, Boorman GA, Kosyk O, Bradford BU, Shymoniak S, Tumurbaatar B, Weinman SA, Melnyk SB, Tryndyak V, Pogribny IP, Rusyn I. Increased incidence of aflatoxin B1-induced liver tumors in hepatitis virus $\mathrm{C}$ transgenic mice. Int J Cancer. 2012; 130:1347-1356. [PubMed: 21500192]

Kaplowitz N. Idiosyncratic drug hepatotoxicity. Nat Rev Drug Discov. 2005; 4:489-499. [PubMed: 15931258]

Kershenobich D, Razavi HA, Cooper CL, Alberti A, Dusheiko GM, Pol S, Zuckerman E, Koike K, Han KH, Wallace CM, Zeuzem S, Negro F. Applying a system approach to forecast the total hepatitis C virus-infected population size: model validation using US data. Liver Int. 2011; 31(Suppl 2):4-17. [PubMed: 21651700]

Koike K, Moriya K, Matsuura Y. Animal models for hepatitis C and related liver disease. Hepatol Res. 2010; 40:69-82. [PubMed: 20156300]

Kopelovich L, Sabine JR. Control of lipid metabolism in hepatomas: effects of fasting and dietary fat on the activities of several glycolytic and Krebs-cycle enzymes in mouse liver and hepatoma BW 7756. Biochim Biophys Acta. 1970; 202:269-276. [PubMed: 4315248]

Korenaga M, Wang T, Li Y, Showalter LA, Chan T, Sun J, Weinman SA. Hepatitis C Virus Core Protein Inhibits Mitochondrial Electron Transport and Increases Reactive Oxygen Species (ROS) Production. J Biol Chem. 2005; 280:37481-37488. [PubMed: 16150732]

Larson AM, Polson J, Fontana RJ, Davern TJ, Lalani E, Hynan LS, Reisch JS, Schiodt FV, Ostapowicz G, Shakil AO, Lee WM. Acetaminophen-induced acute liver failure: results of a United States multicenter, prospective study. Hepatology. 2005; 42:1364-1372. [PubMed: 16317692]

Lavanchy D. The global burden of hepatitis C. Liver Int. 2009; 29(Suppl 1):74-81. [PubMed: 19207969]

Lavonas EJ, Reynolds KM, Dart RC. Therapeutic acetaminophen is not associated with liver injury in children: a systematic review. Pediatrics. 2010; 126:e1430-1444. [PubMed: 21098156]

Lee WM. Acute liver failure in the United States. Seminars in Liver Disease. 2003; 23:217-226. [PubMed: 14523675]

Lee WM. Acetaminophen toxicity: changing perceptions on a social/medical issue. Hepatology. 2007; 46:966-970. [PubMed: 17894320]

Lerat H, Honda M, Beard MR, Loesch K, Sun J, Yang Y, Okuda M, Gosert R, Xiao SY, Weinman SA, Lemon SM. Steatosis and liver cancer in transgenic mice expressing the structural and nonstructural proteins of hepatitis C virus. Gastroenterology. 2002; 122:352-365. [PubMed: 11832450]

Lerat H, Kammoun HL, Hainault I, Merour E, Higgs MR, Callens C, Lemon SM, Foufelle F, Pawlotsky JM. Hepatitis C virus proteins induce lipogenesis and defective triglyceride secretion in transgenic mice. J Biol Chem. 2009; 284:33466-33474. [PubMed: 19808675]

Machida K, Cheng KT, Lai CK, Jeng KS, Sung VM, Lai MM. Hepatitis C virus triggers mitochondrial permeability transition with production of reactive oxygen species, leading to DNA damage and STAT3 activation. Journal of virology. 2006; 80:7199-7207. [PubMed: 16809325]

Machida K, Tsukamoto H, Mkrtchyan H, Duan L, Dynnyk A, Liu HM, Asahina K, Govindarajan S, Ray R, Ou JH, Seki E, Deshaies R, Miyake K, Lai MM. Toll-like receptor 4 mediates synergism 
between alcohol and HCV in hepatic oncogenesis involving stem cell marker Nanog. Proc Natl Acad Sci USA. 2009; 106:1548-1553. [PubMed: 19171902]

Maddox JF, Amuzie CJ, Li M, Newport SW, Sparkenbaugh E, Cuff CF, Pestka JJ, Cantor GH, Roth RA, Ganey PE. Bacterial- and viral-induced inflammation increases sensitivity to acetaminophen hepatotoxicity. J Toxicol Environ Health A. 2010; 73:58-73. [PubMed: 19953420]

Maruyama E, Kojima K, Higashi T, Sakamoto Y. Effect of diet on liver glutathione and glutathione reductase. J Biochem. 1968; 63:398-399. [PubMed: 5671673]

McGill MR, Sharpe MR, Williams CD, Taha M, Curry SC, Jaeschke H. The mechanism underlying acetaminophen-induced hepatotoxicity in humans and mice involves mitochondrial damage and nuclear DNA fragmentation. J Clin Invest. 2012; 122:1574-1583. [PubMed: 22378043]

McGill MR, Yan HM, Ramachandran A, Murray GJ, Rollins DE, Jaeschke H. HepaRG cells: a human model to study mechanisms of acetaminophen hepatotoxicity. Hepatology. 2011; 53:974-982. [PubMed: 21319200]

Mitchell JR, Jollow DJ, Potter WZ, Gillette JR, Brodie BB. Acetaminophen-induced hepatic necrosis. IV. Protective role of glutathione. J Pharmacol Exp Ther. 1973; 187:211-217. [PubMed: 4746329]

Nagy G, Kardon T, Wunderlich L, Szarka A, Kiss A, Schaff Z, Banhegyi G, Mandl J. Acetaminophen induces ER dependent signaling in mouse liver. Arch Biochem Biophys. 2007; 459:273-279. [PubMed: 17207453]

Nguyen GC, Sam J, Thuluvath PJ. Hepatitis C is a predictor of acute liver injury among hospitalizations for acetaminophen overdose in the United States: a nationwide analysis. Hepatology. 2008; 48:1336-1341. [PubMed: 18821593]

Nishina S, Hino K, Korenaga M, Vecchi C, Pietrangelo A, Mizukami Y, Furutani T, Sakai A, Okuda M, Hidaka I, Okita K, Sakaida I. Hepatitis C virus-induced reactive oxygen species raise hepatic iron level in mice by reducing hepcidin transcription. Gastroenterology. 2008; 134:226-238. [PubMed: 18166355]

Nishina S, Korenaga M, Hidaka I, Shinozaki A, Sakai A, Gondo T, Tabuchi M, Kishi F, Hino K. Hepatitis $\mathrm{C}$ virus protein and iron overload induce hepatic steatosis through the unfolded protein response in mice. Liver Int. 2010; 30:683-692. [PubMed: 20214734]

Powell CL, Kosyk O, Ross PK, Schoonhoven R, Boysen G, Swenberg JA, Heinloth AN, Boorman GA, Cunningham ML, Paules RS, Rusyn I. Phenotypic anchoring of acetaminophen-induced oxidative stress with gene expression profiles in rat liver. Toxicol Sci. 2006; 93:213-222. [PubMed: 16751229]

Puoti C, Bellis L, Guarisco R, Dell' Unto O, Spilabotti L, Costanza OM. HCV carriers with normal alanine aminotransferase levels: healthy persons or severely ill patients? Dealing with an everyday clinical problem. Eur J Intern Med. 2010; 21:57-61. [PubMed: 20206870]

Roth RA, Ganey PE. Intrinsic versus idiosyncratic drug-induced hepatotoxicity--two villains or one? J Pharmacol Exp Ther. 2010; 332:692-697. [PubMed: 20019161]

Saito C, Zwingmann C, Jaeschke H. Novel mechanisms of protection against acetaminophen hepatotoxicity in mice by glutathione and N-acetylcysteine. Hepatology. 2010; 51:246-254. [PubMed: 19821517]

Schmidt LE, Dalhoff K, Poulsen HE. Acute versus chronic alcohol consumption in acetaminopheninduced hepatotoxicity. Hepatology. 2002; 35:876-882. [PubMed: 11915034]

Schmittgen TD, Livak KJ. Analyzing real-time PCR data by the comparative C(T) method. Nat Protoc. 2008; 3:1101-1108. [PubMed: 18546601]

Sheikh MY, Choi J, Qadri I, Friedman JE, Sanyal AJ. Hepatitis C virus infection: molecular pathways to metabolic syndrome. Hepatology. 2008; 47:2127-2133. [PubMed: 18446789]

Tan A, Yeh SH, Liu CJ, Cheung C, Chen PJ. Viral hepatocarcinogenesis: from infection to cancer. Liver Int. 2008; 28:175-188. [PubMed: 18251977]

Tryndyak VP, Latendresse JR, Montgomery B, Ross SA, Beland FA, Rusyn I, Pogribny IP. Plasma microRNAs are sensitive indicators of inter-strain differences in the severity of liver injury induced in mice by a choline- and folate-deficient diet. Toxicol Appl Pharmacol. 2012:52-59. [PubMed: 22561871]

Tsai WL, Chung RT. Viral hepatocarcinogenesis. Oncogene. 2010; 29:2309-2324. [PubMed: 20228847] 
Wang T, Weinman SA. Causes and consequences of mitochondrial reactive oxygen species generation in hepatitis C. Journal of gastroenterology and hepatology. 2006; 21(Suppl 3):S34-37. [PubMed: 16958669]

Watkins PB, Kaplowitz N, Slattery JT, Colonese CR, Colucci SV, Stewart PW, Harris SC.

Aminotransferase elevations in healthy adults receiving 4 grams of acetaminophen daily: a randomized controlled trial. Journal of the American Medical Association. 2006; 296:87-93. [PubMed: 16820551]

Yaghi C, Honein K, Boujaoude J, Slim R, Moucari R, Sayegh R. Influence of acetaminophen at therapeutic doses on surrogate markers of severity of acute viral hepatitis. Gastroenterologie clinique et biologique. 2006; 30:763-768. [PubMed: 16801900] 

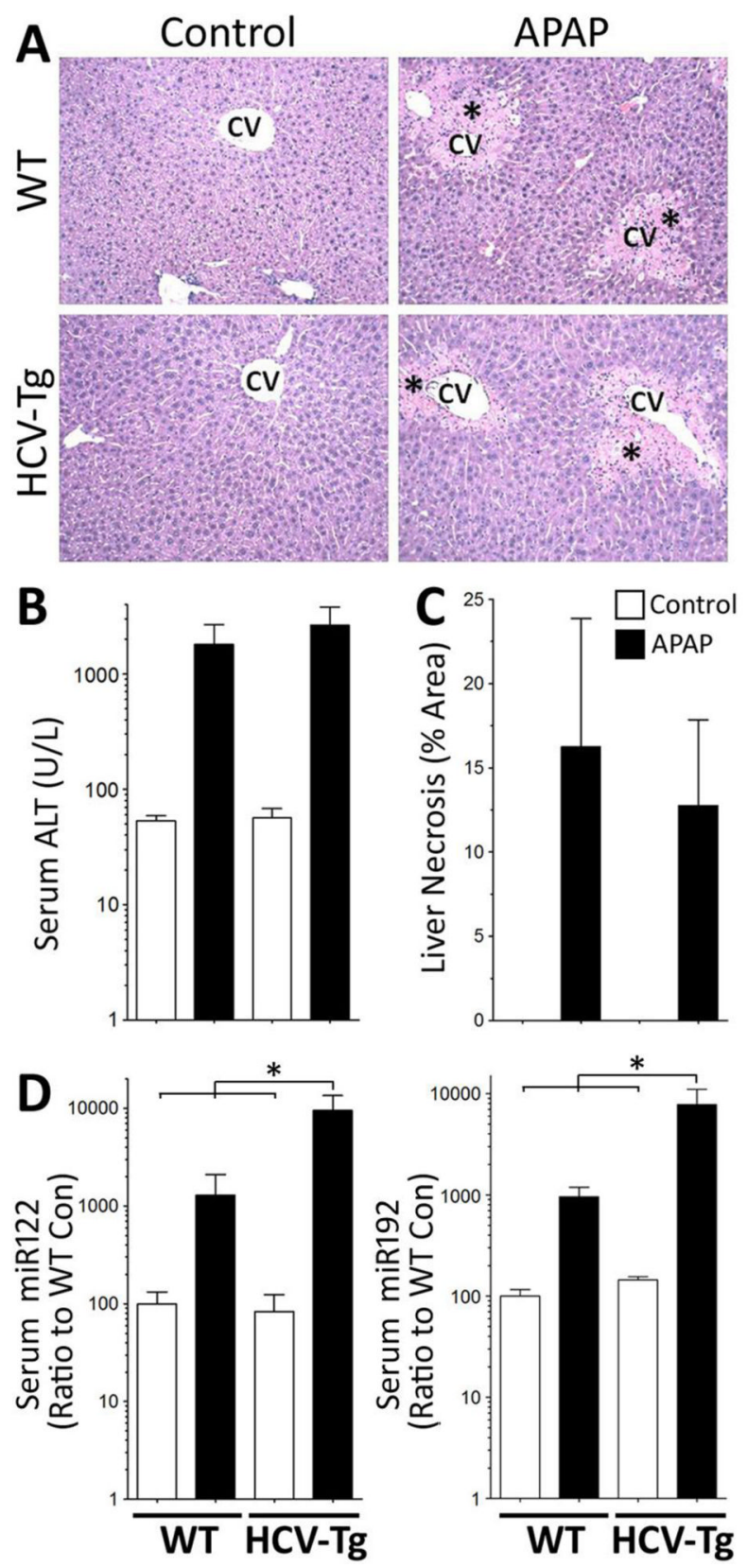

Figure 1. Liver toxicity phenotypes $24 \mathrm{hrs}$ after a single dose of acetaminophen $(300 \mathrm{mg} / \mathrm{kg}$, APAP) in fed wild type (WT) and HCV-Tg mice

(A) Representative photomicrographs of the liver sections (H\&E, 100×). Asterisks indicate centrilobular necrosis with inflammatory cellular infiltration. CV, central vein. (B) Serum ALT levels. (C) Liver necrosis score. (D) Serum expression of miR122 and miR192 relative to levels in wild type control animals. Treatment groups are denoted as indicated in the graphical legend. Data shown are mean \pm SE ( $n=5-10$ /group). Asterisks denote statistical significance from other groups (as indicated by the lines and brackets) at $\mathrm{p}<0.05$. 

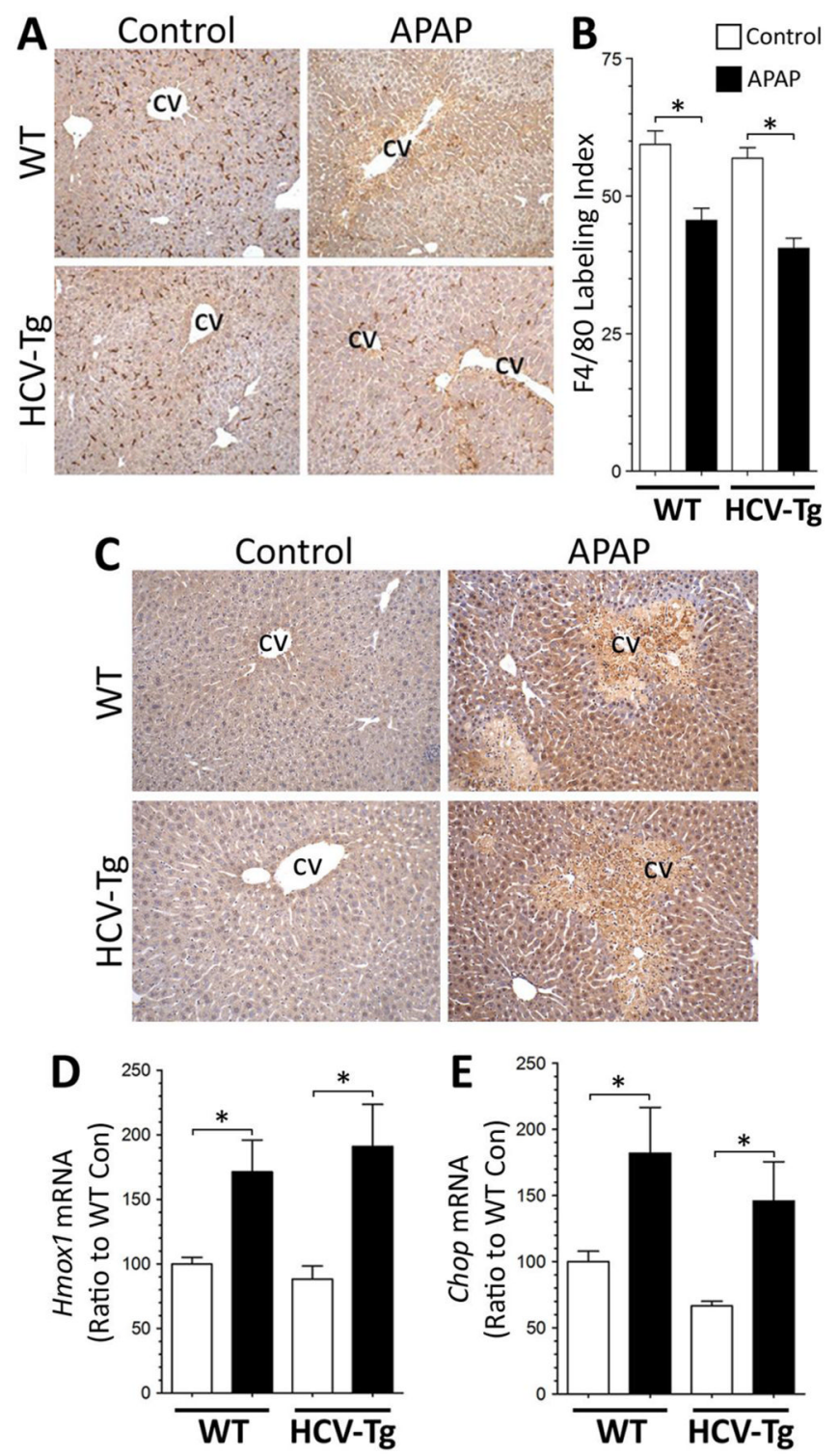

Figure 2. Liver markers of inflammation, oxidative and ER stress 24 hrs after a single dose of APAP in wild type and HCV-Tg mice

(A-B) Liver immunohistochemistry for F4/80. (A) Representative photomicrographs of the liver section (100×); CV, central vein. (B) F4/80 labeling index. The number of F4/80positive cells per $600 \times$ centrilobular field was determined under light microscopy (mean $\pm \mathrm{SE}, \mathrm{n}=5-10$ /group). Five centrilobular areas were counted per tissue sample. (C) Representative photomicrographs $(100 \times)$ of immunohistochemical detection of 4-HNE in mouse liver. (D-E) Liver expression of Hmox 1 and Chop, relative to levels in wild type control animals. Treatment groups are denoted as indicated in the graphical legend. Data shown are mean $\pm \mathrm{SE}(\mathrm{n}=4-5 /$ group). Asterisks indicate significant differences between APAP-treated and corresponding control groups $(\mathrm{p}<0.05)$. 

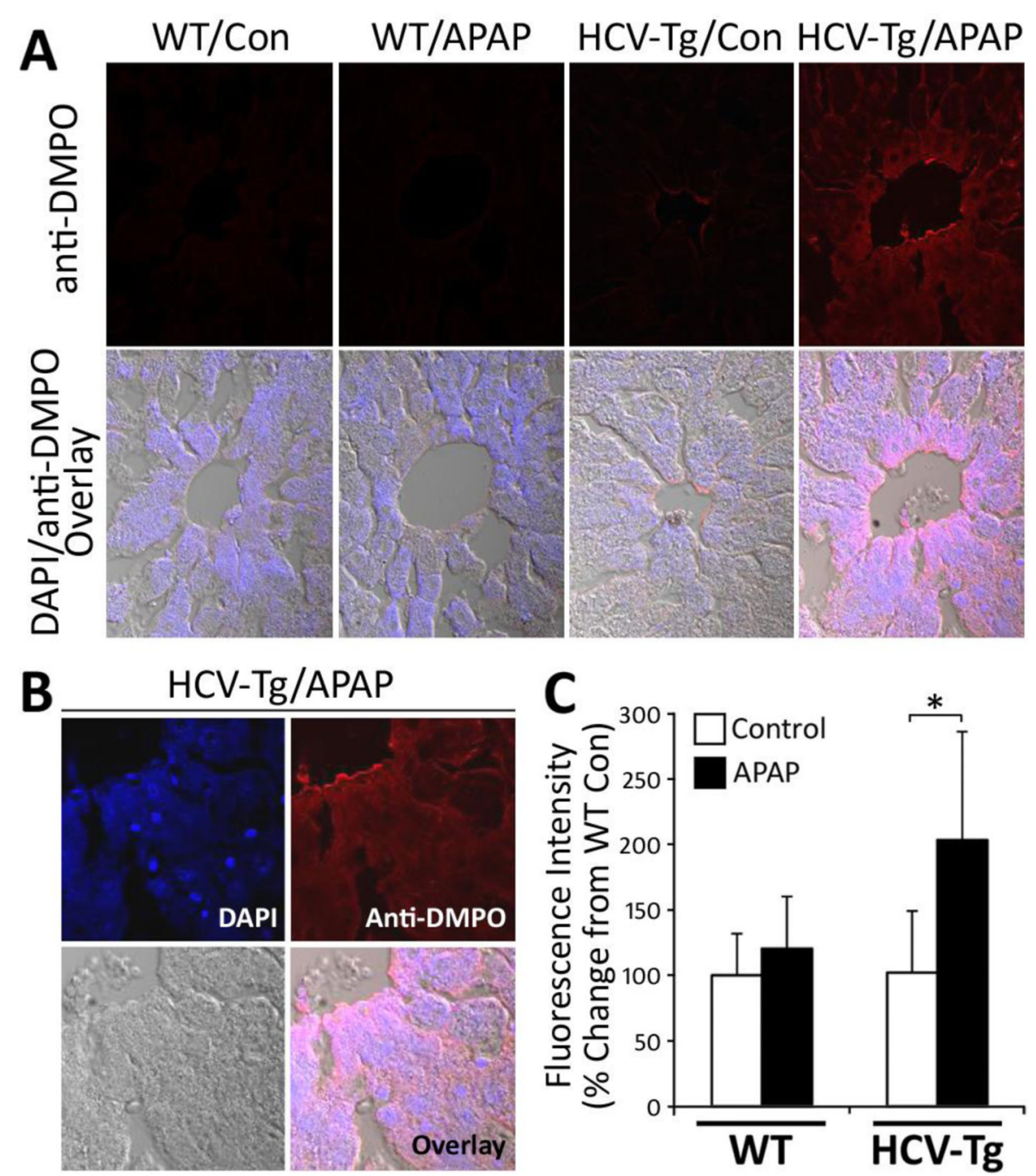

Figure 3. Protein radical formation in APAP-treated mouse liver

(A) Liver sections of DMPO-exposed mice, treated with APAP or vehicle, immunolocalized by anti-DMPO antibody (red) by confocal laser scanning microscopy (40× magnification). Bottom panel shows the overlay of DAPI-stained (nucleic acids stained in blue) and antiDMPO-stained serial liver sections. (B) Representative magnified image $(40 \times \mathrm{zoom})$ of the liver section from $\mathrm{HCV}-\mathrm{Tg}$ mice treated with APAP showing protein radical formation (anti-DMPO; red) in the centrolobular region. (C) Quantification of anti-DMPO fluorescence intensities in WT and HCV-Tg with or without APAP treatment. Treatment groups are denoted as indicated in the graphical legend. Data shown are mean $\pm \mathrm{SE}(\mathrm{n}=3$ / group) expressed as percent change over wild type control groups. Asterisks indicate significant differences between APAP-treated and corresponding control groups $(\mathrm{p}<0.05)$. 

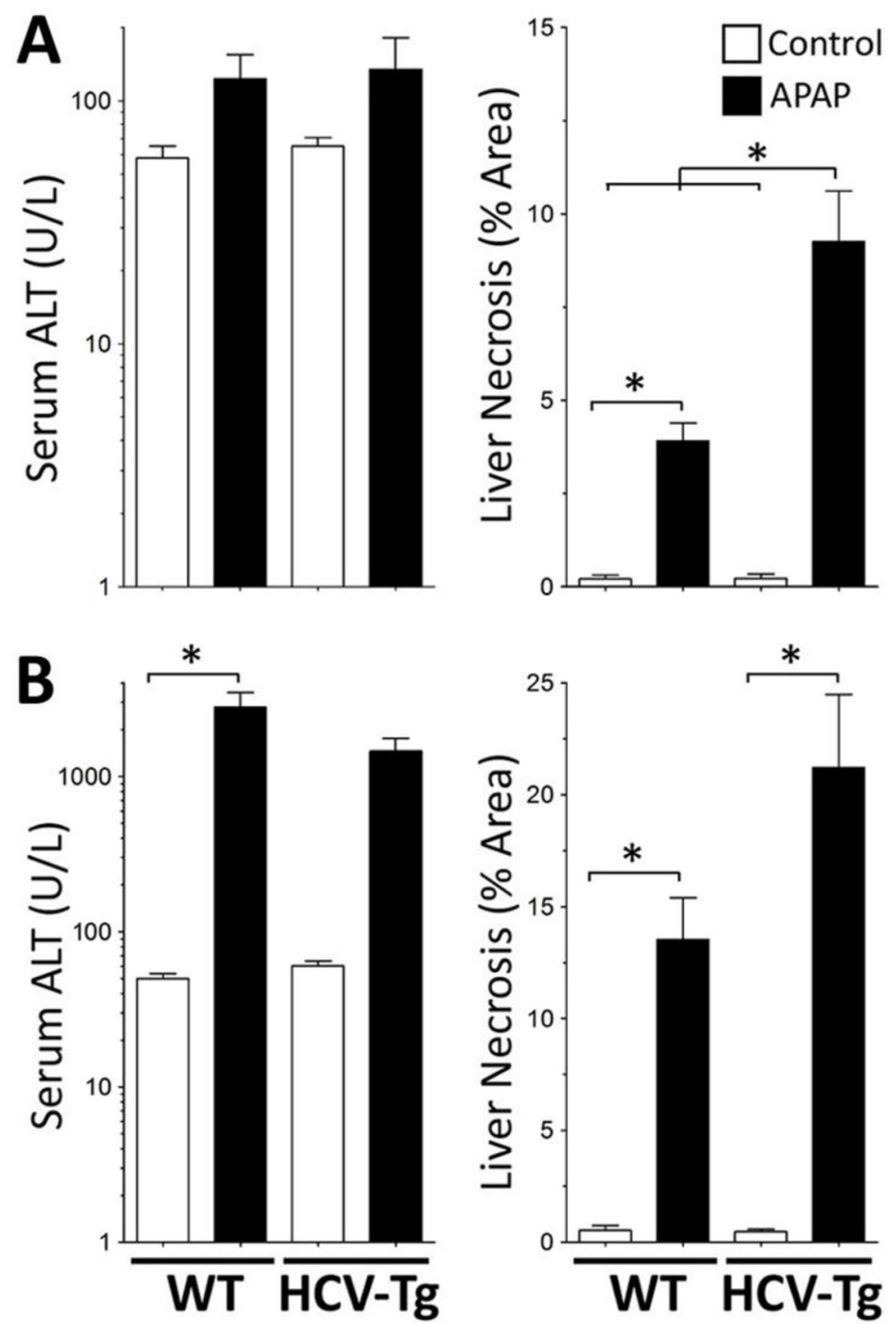

Figure 4. Liver toxicity phenotypes $24 \mathrm{hrs}$ after a single dose of acetaminophen in fasted and fed wild type and HCV-Tg mice

(A) Serum ALT levels and liver necrosis scores in fasted mice treated with $200 \mathrm{mg} / \mathrm{kg}$ acetaminophen. (B) Serum ALT levels and liver necrosis scores in fed mice treated with 500 $\mathrm{mg} / \mathrm{kg}$ acetaminophen. Treatment groups are denoted as indicated in the graphical legend. Data shown are mean $\pm \mathrm{SE}(\mathrm{n}=3-5 /$ group). Asterisks denote statistical significance from other groups (as indicated by the lines and brackets) at $\mathrm{p}<0.05$. 

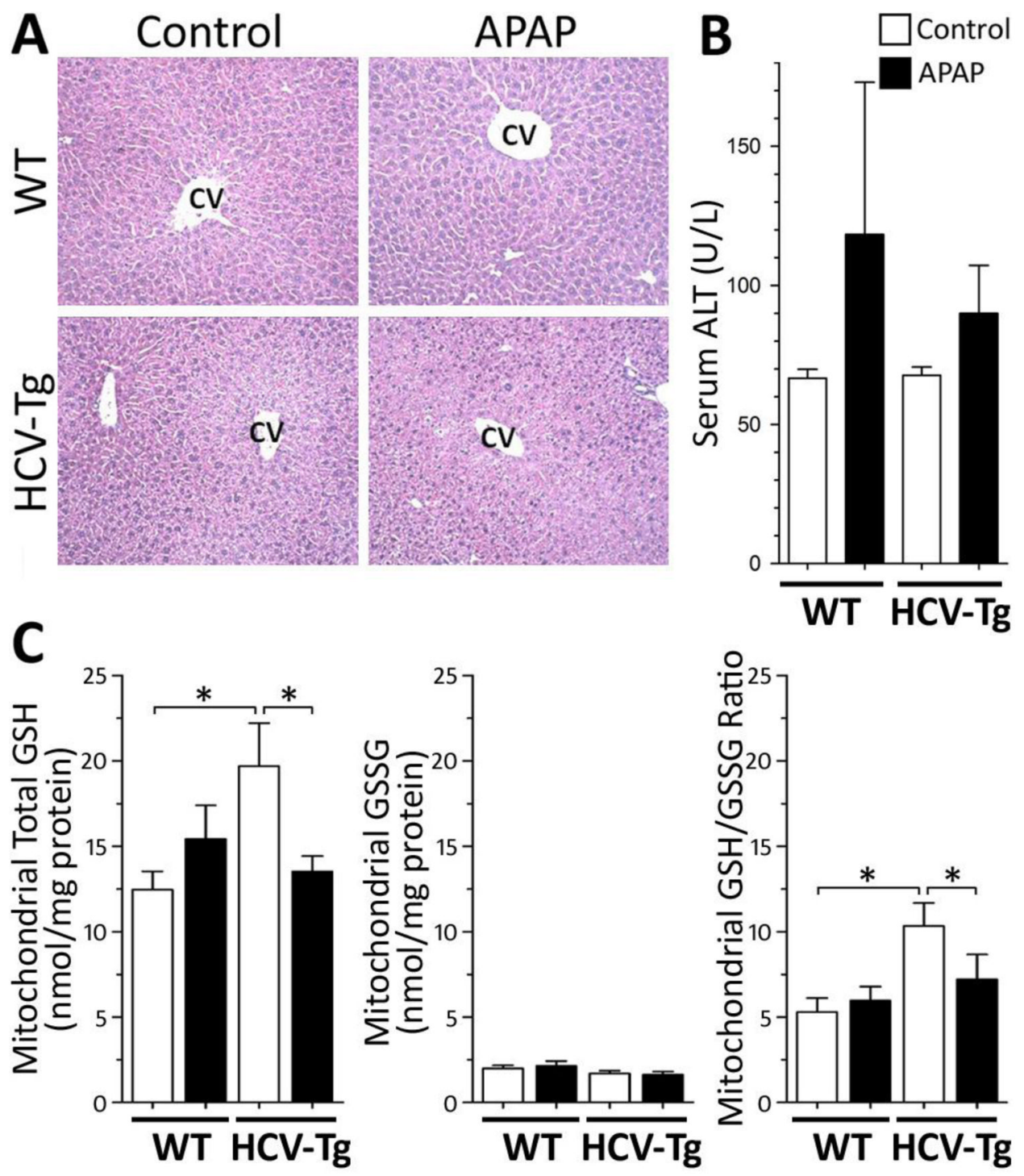

Figure 5. Liver toxicity phenotypes $4 \mathrm{hrs}$ after a single dose of APAP in wild type and HCV-Tg mice

(A) Representative photomicrographs of the liver section (H\&E, 100×), CV, central vein. (B) Serum ALT level (mean \pm SE, $n=6 /$ group). (C) Total and oxidized (GSSG) glutathione levels, and the GSH/GSSG ratio in isolated liver mitochondria (mean \pm SE, $n=3$ /group). Treatment groups are denoted as indicated in the graphical legend. Asterisks indicate significant differences between groups $(\mathrm{p}<0.05)$. 

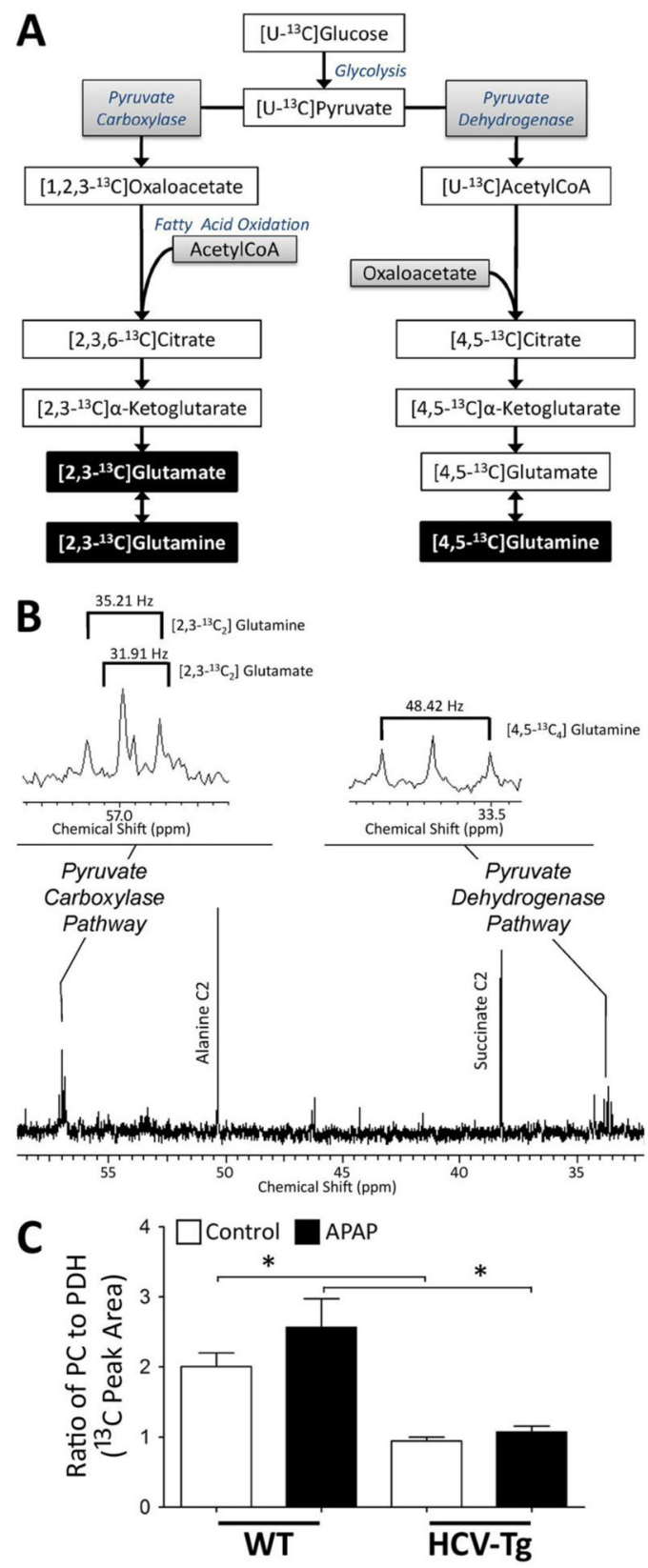

Figure 6. Fluxomic analysis of liver energy metabolism

(A) Labeling of metabolites from $\left[\mathrm{U}_{-}{ }^{13} \mathrm{C}\right]$ glucose via pyruvate dehydrogenase (PDH) and pyruvate carboxylase (PC). $\left[4,5-{ }^{13} \mathrm{C}\right]$ Glutamate is exclusively formed via PDH by the first turn of the Krebs cycle where the isotopomer $\left[2,3-{ }^{13} \mathrm{C}\right]$ glutamate is exclusively formed via PC. Repeat turns of the Krebs cycle result in related ${ }^{13} \mathrm{C}$ isotopomers of glutamine, but these are at low fractional enrichment and can be neglected (see Supplementary Information for details). (B) A representative ${ }^{13} \mathrm{C}$ NMR spectrum of liver from wild-type control with enlargements of the NMR peaks representing the $\mathrm{C} 2$ and $\mathrm{C} 4$ positions of glutamine and glutamate (inset). This illustrates the ${ }^{13} \mathrm{C}-{ }^{13} \mathrm{C}$ couplings of the peaks representing the ${ }^{13} \mathrm{C}$ isotopomers, $2,3-{ }^{13} \mathrm{C}$-glutamine, $2,3-{ }^{13} \mathrm{C}$-glutamate, and $4,5-{ }^{13} \mathrm{C}$-glutamine. The assignment of isotopomers is based on comparison with coupling constants from the literature (Carvalho et al., 1999). 